\title{
The Deconstruction of Women Image Through Advertising
}

\author{
Didem Zeynep BAYAZIT iD a
}

a Istanbul Commerce University, Department of Business Administration, İstanbul, Turkey. zbayazit@ticaret.edu.tr

\begin{tabular}{|c|c|}
\hline ARTICLE INFO & ABSTRACT \\
\hline $\begin{array}{l}\text { Keywords: } \\
\text { Advertising Communication } \\
\text { Process } \\
\text { Advertising Content } \\
\text { Objectification of Woman }\end{array}$ & $\begin{array}{l}\text { Purpose - In our daily lives, we are faced with millions of products/services that are waiting to be } \\
\text { consumed and ads are trying to govern individuals' perception by using themes such as luxury, } \\
\text { fantasy, beauty, attraction, entertainment and irritation. The goal of this study is to focus on } \\
\text { advertising communication process through advertisement content creation as an effective tool. It is } \\
\text { also necessary to draw attention to the importance of advertising content subjects and to argue how } \\
\text { women are trivialized, underrepresented and objectified in advertising. }\end{array}$ \\
\hline $\begin{array}{l}\text { Received } 20 \text { November } 2019 \\
\text { Revised } 10 \text { February } 2020\end{array}$ & $\begin{array}{l}\text { Design/methodology/approach - This study is constructed through a qualitative analysis which } \\
\text { uses convenient sampling method. The purpose of the study is to underline and advance theory, } \\
\text { research and practice regarding the image of women as incompetent, useless, sexual objects and } \\
\text { likened to a meta in advertisements from different sectors. }\end{array}$ \\
\hline $\begin{array}{l}\text { Article Classification: } \\
\text { Research Article }\end{array}$ & $\begin{array}{l}\text { Findings - It has been recognized through literature that various images in advertising has more } \\
\text { impact power rather than the rest of the images. The portrayal of women in advertising has been } \\
\text { believed to be the one of the most powerful images which is mostly used as an object- for increasing } \\
\text { effectiveness, awareness, recall power and sales rate of the products. Specifically, findings have } \\
\text { concluded that most of the advertisements purposely promote objectification of women to preclude } \\
\text { their individual advancement in the society. }\end{array}$ \\
\hline & $\begin{array}{l}\text { Discussion - Objectification is an ethical concern that needs to be sensitively criticized and debated } \\
\text { about "how the women should be portrayed?". Specifically, advertising industry should consider } \\
\text { effectively reproducing the image of 'women' according to society's values and should not to } \\
\text { represent their image in negative formats. }\end{array}$ \\
\hline
\end{tabular}

\section{INTRODUCTION}

Today, the developments in information and communication technologies have brought about a significant transformation in the contextual, formal and instrumental structure of communication. Both conventional and new media are an effective communication media which shape and direct the existence of a society by establishing a complex interrelationship (Booth, 2010:1-4). Rapidly developing communication technologies have been effective in all printed, audio-visual, kinesthetic, digital and multimedia contents which have always been in a renewed, rapidly consumed and interactive position (Sutcliffe, 2008:1-2; Neumann and Neumann, 2015:204). Beyond the information age, or so-called experience age, the 'visuality' has evolved into advertising and has both positively and negatively impacted our lives. Advertising is a significant form of representation of signs and meanings in an existent culture and transforms these with advertised brands. Advertisements can be evaluated as sensual and vigorous reflections of cultural value and serve as a fundamental to change in society (Hackley, 2005:4; Richards et al., 2013:9-10). According to Pedersen (2002:303-304) the media has a significant impact on creating, shaping and sustaining societal perspectives, generating and transmitting gender differences and inequality through daily visuals.

Since 'visuality' is considered as the new plague of our age, advertising plays a crucial role to have benefited from it. This creates undeniable pressure, especially on women who were believed to be represented as the most attractive supplemental image of the advertising's content strategy. Advertisements, which offer a lifestyle and a way of behavior when marketing products to the consumer, have used women as an object of exploitation and commodity for years. The female portraits and their idealized image of beauty, sexual appeals, gender roles, submissive visuals have served as a reason for objectification in advertising and have received considerable attention from multidisciplinary scholars/theorists (Courtney and Lockeretz, 1971; Belkaoui and Belkaoui, 1976; Whipple and Courtney, 1985; Richmond and Hartman,1982 ; Soley and Reid, 
1988; Lundstrom et al., 1999; Reichert, 2002; Zimmerman and Dahlberg, 2008; Bernard et al, 2012). According to Ducoffe (1996:23-24) consumers may perceive ads as irritating and undesirable, depending on the techniques and contents used in. According to Barnes Jr. and Dotson (1990:62) advertisements can be found offensive for its executions. The offensive executions of women used in an advertisement tend to lead consumers to evaluate advertising by the overall worth they receive from the representations in the ads. Therefore, advertising content has the direct influence power on the credibility and value of the advertised brand.

In this study, firstly the advertising communication process will be discussed, secondly an attention will be drawn to the importance of content subjects and the use of women image in a content and last, critical analysis of irritative advertising examples will be executed to show how women are trivialized, underrepresented and objectified.

\section{LITERATURE REVIEW}

\subsection{Advertising Communication Process}

Advertising is the most sensational form of marketing communication in the late (post)modern society. It is defined as any paid form of non-personal communication by an identified sponsor, using media to inform, persuade or influence an audience (Belch and Belch, 2012:18; Moriarty et al., 2006:97). The classic model of communication, which has an interdisciplinary quality, employed by advertisers involves a source/sender who encodes a message- puts in words and signs- which is then transmitted through an appropriate medium to a receiver who, is the listener, viewer, or reader (object of the information), decodes that message to persuade or reinforce attitudes (Duncan and Moriarty, 1998:2; Richards and Curran, 2002:74). In a traditional or digital communication culture there are three forms of sharing: sharing of codes, sharing of content and sharing of access (Cammaerts, 2011:48). All these sharing forms take place in between sender and receiver. According to Mick and Politi (1989:86) any form of sharing between sender and receiver should have researched carefully for maximizing communication effectiveness. Richard and Curran (2002:74) suggest that advertising, as a form of communication, triggers attitude change of an exposed consumer.

Advertising and interpersonal communication are likely to be the two forms of communication that they both have concern about the receiver's reaction (Nan and Faber, 2004:14). Stern (1994:8) transforms Laswell's (1948) speech model of "source (who)-message (tells what)-receiver (to whom)" generic entities into 'sponsor (source)advertisement (content)-consumer (receiver)' which are considered as marketing terms relevant to advertising. This revised advertising communication model proposes a text-based rather than speech-based in an advertising context. In addition to those structural elements, noise and feedback components are also taken into consideration to form the effective structure form of communication model (McGuire, 1985:234). Stern (1994:8) defines the source as sponsor, author, and persona: the sponsor entity is represented as whose communicative responsibilities include paying/ approving the ad and not necessarily the function of message creation, but they are legally liable for every action; the author(s) entity represents the all contributors (representatives of the sponsor/client firm/brand and advertising agency staff-copywriters, art directors etc.-) in the creativity process; the persona resides within the textual world and is a part of the ad discourse. The credibility and attractiveness of the source variables are very important. Source variable refer to the attributes of the source of the messages (Nan and Faber, 2004:13) The message represents the advertising content advertisement-. According to Ducoffe (1996:365) advertising messages are presented as a communication exchange between advertisers and consumers. It is necessary for all parties to generate value for both in order to communicate effectively. The advertising message is an important measurement criterion to asses advertising effectiveness. The ad message is based on three variety of forms: autobiography employs a firstperson persona "I telling the story", narrative employs a third person persona like a story "he-she-it telling the story" and drama employs a "narration", allowing characters to act out directly (Stern 1994: 10). The consumer is the receiver. There are three types of consumers: implied, sponsorial and actual (Stern 1994: 10). Implied consumers are the ones presumed within the ads, sponsorials are the representatives who determine whether the ad publishes-gatekeepers etc., and actuals are the ones who are the real-time consumers and represent the target market that they produce meaning by participating in a socially constructed practices (Mc Laughlin, 1990: 6). The consumer become the co-creator of meaning as a being the responder (Stern 1989:323). 
Advertising representations create a connection between meaning and language of concepts and signs with the culture (Hall, 1997:18). The used images-signs in advertising signify and create a meaning of something that exists in the real world, or an imaginary thing of an ideal representation (Kates and Shaw-Garlock, 1999:33). Hereby, in an advertisement message/content the choice of words, images, and grammatical style, rhetorical structure conduct a basis about the company, product and the consumer (Stern, 1988:5). In interactive advertising, the interrelation of message types and changes in media platforms entail to generate potential and necessary meanings made possible by the content (Stern, 1994:8). In order for advertising communication to be successful, the target audience should be exposed via proper channel and process the content in an intended manner to relate the content's subject with the sponsored brand (Rossiter and Percy, 1985: 510).

\subsection{Advertising's Unfavorable Image: 'Woman'}

\subsubsection{Credible Content}

Individuals' view of the world and their attitude towards the world are shaped by the effective use of media platforms and especially advertising. Graber (2010:3) notes that all types of media present a set of cultural values through content creations to the audience that are likely to accept in whole or in parts to define the typicality set of the society. Norris and Colman (1992:38) claim that it is easier to internalize advertising content when there is a meaningful exposure attack. According to Kim (2018: 848) research on online advertising indicates that a forced exposure attack by tracking consumer behavior increases the awareness of the advertisement, but also this has been criticized by many scholars as consumers may interpret this kind of intrusion as frustrating/irritating. According to Paxson (2018:17) advertising contents don't construct reality, rather they create a value system by blurring reflections of how consumer interpret reality. Most ad content is presented as the only element that can transform and change the life of the consumer with fantasies, not as a consumable commodity (Bearden \& Etzel, 1982:194; Dines et al., 1998:49).

Ducoffe (1996) indicates that the advertising content serving as a groundwork to advertising value. While creating the content strategy, the choice of an advertising appeal is very important. Advertising appeals are categorized into two types, rational and emotional (Turley and Kelley, 1997:40). Rational appeals encourage rational decision-making process, which involves continual search for alternatives of the best combination of quality, service and price (Moore et al., 1995:155). Emotional appeals communicate the emotional end-benefit of gaining the product and that is why the company needs to dramatize advertising content (Stern, 1988:13). Cutler and Javalgi (1993:67) suggest that message appeals and personalized headline/taglines (containing "you, your") in an advertising content trigger emotional involvement and increase the effectiveness of the advertising. Advertising content increases the tangibility of any kind of product, if the product is portrayed properly or by using significant symbolic representations within the visual (Cutler and Javalgi 1993:67). Visuals in the content are believed to be pivotal tools to form an effective and powerful advertising communication.

Ducoffe (1996:366-367) focuses on the subjects of the content and he identifies three main subjects for the content: informative, entertaining and irritative.

1. Informative: Advertising informs potential/actual customers about the availability of the products and products' experience characteristics (Ackerberg, 2001:319). According to Stern et al. (1981) informative content categories are as follows: price, quality, performance, components and content, availability, special offers, taste, nutrition, packaging, shape, guarantees and warranties, safety, independent research, company research and new ideas.

2. Entertaining: Entertaining content should provide consumer to satisfy needs of escape, aesthetics, or emotional release. An entertaining content is perceivably evaluated as positive by the receivers. According to Taylor (2009:415) traditional advertising messages rely on more informational approaches rather than digital contents. Humorous approaches and entertaining contents are more likely to be associated with convincing consumer to respond as expectedly.

3. Irritative: Advertising content is constructed with variables which may offend or manipulate consumers. Irritation is the state of feeling annoyed, angry or displeased. This type of content disturbs consumers and distorts the message received. According to Fritz (1979:2; Sparks and Lang, 2015: 158) highly irritating and relatively pleasant advertising themes generate higher 


\section{Z. Bayazit 12/1 (2020) 429-439}

receiver's recall, higher level of appetitive reaction and highest resource allocations. An ad with unrelated content is likely to distract consumer, get him/her off-focus and lead to irritation towards the ad, brand and company.

Above all content subjects, informativeness is the most significant factor strongly correlated with overall advertising value (Ducoffe,1995: 18).

In particular, this study discusses the portrayal of woman as an object in advertising content as "irritating". Although advertisers believe to find these irritating contents highly effective for consumer's recall probability, the use of any content that degrades the woman's value in a society, even for entertainment purposes, is not considered a rational approach.

\subsubsection{Objectification of Woman in Content}

Humanity has been using vocalization, ritualized behaviors and visual displays in creative actions and communication to configure sense of symbolic meanings (Morris-Kay, 2010:158). Advertisements shape the public's interpretation of reality with images/visuals they transmit. According to Bordo (1989:20) women constitute a visual of body images to standardize femininity as normal, ideal or -more likely- defective. Woman image is a rich symbol, laden with culturally crafted meanings (Frederick and Roberts, 1997:173). Correspondingly, advertisements produce norms and standards on a mass scale for presenting 'ideals' and they stress to make the formed woman image recognizable (Kilbourne, 2012:173). Advertisers have been challenged and charged with portraying visual displays like women in narrow, old-fashion, and disapproval manner (Courtney and Lockeretz, 1971:92; Leigh et al., 1987; 54). Many scholars discuss that the perception of the advertised product is created in a way by linking it with creating meaningful content, inspired connotations, and using 'powerful images' (Warne, 1962:11; Davies, 2012: 112). Although minority of studies have found that males are objectified -used as a powerful image- in advertising, literally scholars have long argued that women are considered to be often objectified when the content focus is directed toward their physical qualities and images rather than mental ones (Heflick and Goldenberg, 2014:225-226; Onay, 2017: 170). Fredrickson and Roberts (1997:173-4) have proposed the objectification theory as a framework for understanding the consequences of being woman in a culture that objectifies woman sexuality like a product. The theoretical frameworks suggest that placing female bodies in a sociocultural context encounters sexual objectification and women mostly presented like an object. The threat in objectification in advertisements is that the real purpose of the content is dimmed and only the body or the body parts are used as commodities, and the women are passivated for consumption by others. Since 1960s with the rebirth of the women's movement, the way advertising treats woman has been criticized. Although many changes have occurred in the advertising industry since 1980s, due the women's protests by feminists and sociocultural theorists, still today the way how advertising represents women is generally unapproved and questionable (Zimmerman and Dahlberg, 2008:71).

Solomon (1992:11) notes that one of the basic tenets of advertising is to persuade consumers to buy the product and to form positive feelings about the brand and company. It seems that an attractive woman model associated with a product or message has an attractive power in consumers' evaluation of the brands. Studies have shown that women are gazed more than man and they are more likely to be 'looked at' (Frederickson and Robert, 1997:176). Most directly, ad audiences were observed to have more interest in looking physical appearances of women rather than their personality features. Most of the portrayals in advertising have a vivid interest of objectifying woman as a decorative tool (Kyrousi et al., 2016:773). Particularly, it has been argued that advertising, as a primary communication tool, indecently introduces and promotes underrepresented woman role and/or image, such as sex object, happy housewife, mother, supermodelwatchable object, incompetent and dependent to a man (Leigh et al., 1987:55; Courtney and Lockeretz,1971:92; Belkaoui and Belkaoui, 1976:172, 1976: Ferguson et al., 1990:41; Whipple and Courtney, 1985:6; Boddewyn, 2013:25; Gudekli and Celik, 2014:6131; Grau and Zotos, 2016: 762). With modern approaches, to the portrayal of woman is described little different then traditional approaches which a woman must have "happiness, personal competence, professional life, strong will, and the body that is always young and perfect" (Kose, 2011:78). Courtney and Lockeretz (1971:93) argue that most of the time women are presented in advertising as sexual object and are not regarded as whole person with full of other qualities. Reichert (2002:242) points out that sexuality of woman and sexual images of advertising content are used as a drive for consumption for both 
women and men. Ulusoy (2007:310) concludes that advertisements reduce sensitivity to social changes and values by playing over physical desires, and human body, specifically by fulfilling needs with the sexually used women images. It doesn't matter if the woman portrayals of advertisements signify traditional or modern look, in general, findings reveal that sexual content, specifically objectification of woman, triggers appetitive activation therefore, relevant content features construct a primary motivation toward the advertised brand (Sparks and Lang, 2015:136-138).

\section{METHODOLOGY - Critical View of Ads Showing Woman Objectified}

As stated above, a known criticism is that advertising is a widespread cultural institution that often represents women in an irritating way like a decorative meta with their physical appearance and a watchable/desirable object. The problematic construction of interpreting the meanings of ads which women are objectified changes the social positioning(s) of women in the society. This qualitative study has analyzed advertisements from different sectors using convenient sampling method. Conveniently selected advertisements from different sectors without a time frame should be considered as the limitation of this research. The purpose here is to underline how the image of women is shown as incompetent, useless, sexual object, and likened to a meta regardless of pointing out to specific sectors.

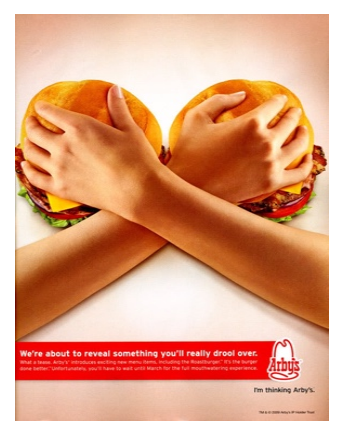

Figure 1. Arby's Advertising Campaign, 2009

2009 SI Swimsuit Issue Advertisement (Adams, 2016:73)

Arby's full-page ad has published in the 2009 Sports Illustrated Swimsuit Issue. The ad demonstrates that a pair of oversized roast-beef burgers, represented as female breasts, are held by a model's crossed arms. The tagline is "We're about to reveal something you'll really drool over." Arby's plans to capture attention of viewers by showing two burger buns as though they are taking off a bikini top and the brand actually tries to announce the new upcoming burger through creating awareness (Adams, 2016:73). Apparently, Arby's aim to create this so-called irritating content is to persuade the young male viewers of the magazine and the visual creates a fantasy as through implying that eating Arby's burgers will make you feel like eating a woman's sensitive body part. The brand creates a new social meaning by reproducing the idea that women breasts are like hamburgers. By objectifying woman as a food that can be desired and consumed, the brand has underrepresented woman like an object and offend them by taking a risk of losing them.

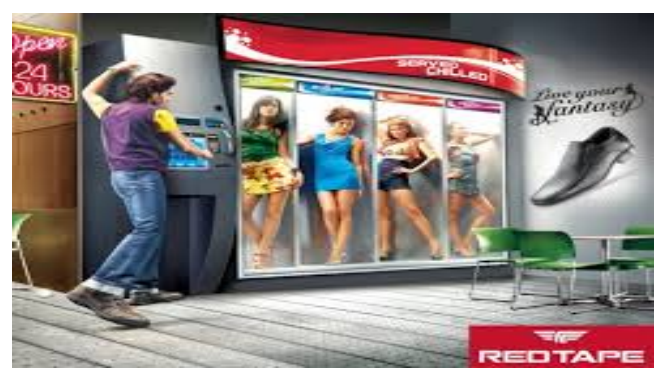

Figure 2. Red Tape Advertising Campaign, 2009

https://thesocietypages.org/socimages/2009/12/26/redtape-shoes-live-your-fantasy-campaign/

Red Tape's print advertisement is created by Makani agency. Red Tape is a premium lifestyle Indian brand. The Red Tape, an international brand, has range of shoes, apparels and accessories for Men across the globe. The ad's content promotes Red Tape shoes. In the advertisement, a guy gets to select one of these four women, who dressed and styled sexually, placed in a vending machine for his own pleasure. "It is the ultimate form 
of objectification- women as something to pick from and purchase at a leisure" (Sharp, 2009). The tagline of the campaign is "Live your Fantasy". The question here is whether this ad is designed for promoting shoes or to state that women look like a fantasy product like a 'drink' and turn into a meta that can be bought and kept under control? Clearly, the ad has nothing to do with its purpose of creating awareness to Red Tape shoes in the content, rather it degrades the meaning of being a woman and proves the fact for demonstrating the male power over woman by underlying gender inequality as in most of the advertisements. The visual presents purposely women as incompetent and their existence can only be described by dressing up in shorts and tight clothes just to show off their beautiful bodies as an icon/object. Since, the main target of the brand consists of men consumers, it is expected from the sector to use objectified representation of women appeals to attract men and lead their desires.

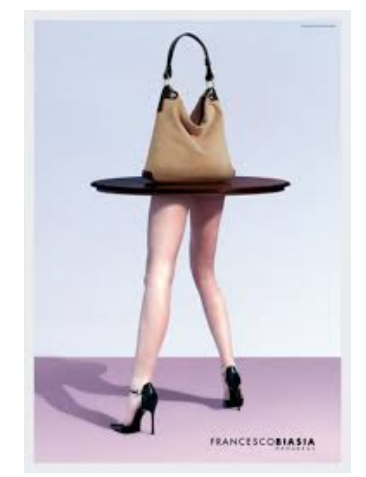

Figure 3. Francesco Biasia Advertising Campaign, 2002

https://www.luerzersarchive.com/en/magazine/print-detail/francesco-biasia-21282.html

Francesco Biasia is an Italian brand for bags and accessories. The brand defines itself as the creator of highimpact look. The brand usually advertises its bags using sexually objectifying images of mostly women's body parts. The chosen ad at the indicative level, presents a bag is sitting on a circular tabletop. The irritative part of the advertisement is that the legs of this table, are those of a woman, rather than any other material such as wood, steel or etc. Those legs aren't any legs but are demonstrated as long and sexy legs of a woman perhaps in her mid 20s. In using these two particular images, the advertisers illustrate that there is further than a bag to think about in this advertisement. The point of view here is the further thinking represents objectifying woman by using the lower half of her body as a stand-in for a table. This other controversial and irritating ad emphasize that the image of women is as unnecessary as possible, except for the presence of only body parts.

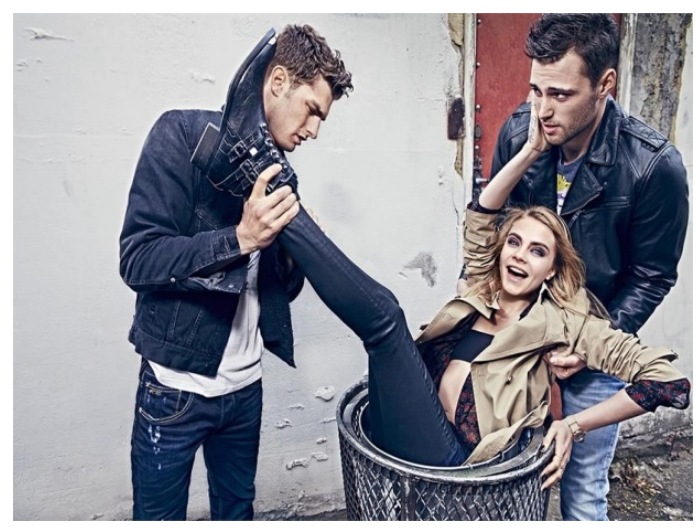

Figure 4. Pepe Jeans' Advertising Campaign, 2014

Fall/Winter Advertising Campaign, 2014

\section{https://www.youtube.com/watch?v=aRZzBW-9MyM}

Pepe Jeans is a denim pioneer brand based in London. The brand has collaborated with 'Cara Delevinge' to be the Fall-Winter 2014 campaign face. Mostly, the overall purpose of using celebrity endorsement is to appeal target audience and to create a massive advertising effect. Although such advertising strategies are considered to have positive results, there is much to criticize this campaign image. The visual depicts that two men holding a woman's arms and legs throw her, like a garbage, in the garbage bin. When we look at this visual, 
there is an irritative simulation between woman and garbage. The image of 'perfection-supermodel' is framed as a 'useless/unnecessary product-garbage'. In both cases, the celebrity has used as her looks rather than her intelligence. At a social level, the profound effect of objectifying treatment is destructing women's self-esteem and positioning in life.

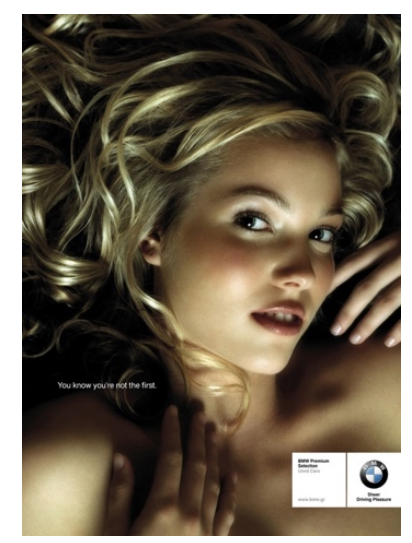

Figure 5. BMW's Advertising Campaign, 2008

Used Cars Provocative Campaign, 2008 (Green, 2013)

BMW's, German automaker brand, 2008 advertising campaign for second hand cars is another example for controversial advertising. The ad is created by BBDO Greece and first published in Greece. This advertisement portrays a young, blonde and light-eyed female model lying in bed, looking seductively at the camera. The tagline of the ad, 'You know you're not the first. But do you really care?' promotes an explicit sexual connotation; it is emphasized that the young woman has had sex at least once and that nobody should care about before. The ad has caused an outrage sound in the advertising world, because there is no car in the ad instead only a seductively looking young blonde woman. Most of the automotive companies utilize the sexual objectification power suggestions in their advertisements. Cars are like a 'sex' object. In general, since women are the ones to represent sexuality, women and cars are inseparable while forming an automotive ad's strategy. Obviously, this ad has a strong use of sexual objectification of a woman being likened to a commodity-second hand car- and it is placing women again to an incompetent level as a sexual object.

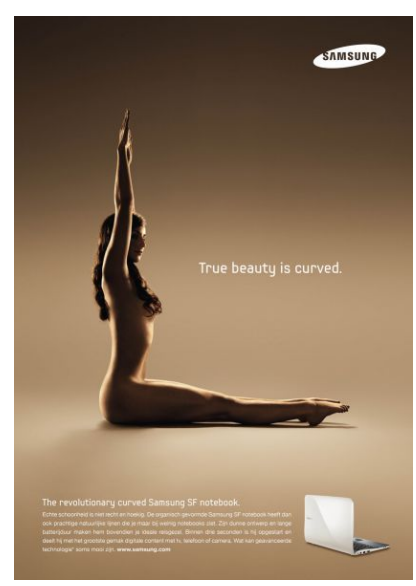

Figure 6: Samsung SF Notebook, 2010

\section{https://www.adsoftheworld.com/media/print/samsung true beauty is curved}

Samsung, a South Korean company, is one of the world's largest producers of electronic devices. Samsung's 'revolutionary curved SF Notebook' advertising has created by Cheil Agency. The main issue with this specific campaign is the unnecessary display of the naked woman. In the commercial, the girl is displayed for a longer time than the actual laptop. Usually, technology products are expected to use informative content rather than irritative content of advertising. The question here is, how a naked woman can be related with the looks and function of a laptop? The commercial backs up the tagline of "True beauty is curved" and it supposedly tries to represent an image of 'true beauty' with a thin naked woman, touching her curves and smoothness, to somehow show the delicate feeling and perfectly structured figure is the same as the laptop. In the ad, the 
woman's naked and perfectly shaped body is clearly used to be evident that women are being dehumanized and transformed to a sexual object.

Although these advertising examples endeavor to demonstrate the objectification of woman, the proposed content analysis is limited to selective samples and lack of consumer's reactions to such advertisements bear limitation. Today, unlike traditional media, the openness of the participatory technologies, such as social media, allow the public to show sudden responds to an advertisement or to discuss an advertisement with communities and make their voice heard easily (Feng et al, 2019:292). Malthouse and Li (2017:228) note that social media is the world's largest focus group that can provide advertisers insights on how consumers behave and feel about a brand and in return they can improve their strategies to form proper contents.

\section{CONCLUSION}

In today's societies, the contents and displays that are created for women and women's physical appearance should be considered in relation to the social and psychological position of women. Objectification is a hassle that needs to be sensitively criticized and debated about how the women should be portrayed and the underrepresentation of women has a direct effect of on societies. Media, specifically advertising industry, must reproduce the image of 'woman' in an effective format according to social conditions, not to blur and underrepresent the woman image. Instead of objectification of women in advertisements, importance should be given to the content to create value and respect. Advertisers need to monitor their content creations and adjust their strategies accordingly. Consequently, women's roles in the society have evolved over the past few decades, but advertisers are still faltering to mirror those changes on how to represent woman.

Such portrayals of objectification of women go against our own personal value systems, if we accept such appeals of women in advertising, then with no offence we will be directed to accept the results of frustration in the society. In parallel with this result, the viewers will become desensitized to such executions, and woman image will get stuck in manipulative advertising contents. The social value system doesn't appreciate the stereotyping, gender inequality, sexual and useless images, objectification of women, rather it is expected for companies to promote the mental aspects and capabilities for all genders in advertisements to avoid offensive reactions. There is a growing trend in advertising, termed as 'Femvertising', which appropriates women's value and their empowerment to encourage consumption, still today this strategy has not been seriously adapted by most of the brands and advertisers. Deliberately, selecting such degraded women images and ensuring that they are represented in advertisements over and over again, destruct the social values and acceptance of equality between genders.

Hereby, future researches on the subject may conduct to detailed experiment to analyze the impact of real time comments on ads and to test the viewer's responses and opinions to these irritating advertisements that often use objectification of women.

\section{References:}

Ackerberg, D. A. (2001). Empirically Distinguishing Informative and Prestige Effects of Advertising, Journal of Economics, 32(2), 316-333.

Adams, C. J. (2016). The Carol J. Adams Reader: Writing and Conversations 1995-2015, USA, Bloomsburry Pub.

Barnes Jr., J. H. and Dotson, M. J. (1990). An exploratory investigation into the nature of offensive television advertising, Journal of Advertising, 19 (September), 61-69.

Bearden, W. \& Etzel, M. (1982). Reference Group Influence on Product and Brand Purchase Decisions, Journal of Consumer Research, 9 (September),183-194.

Belch, G. \& Belch, M. (2012). Advertising and Promotion an Integrated Marketing Communication, 9th ed., New York, McGraw-Hill.

BelkaouI, A. and Belkaoui, J. M. (1976). A Comparative analysis of the Roles Portrayed by Women in Print Advertisements: 1958, 1970, 1972, Journal of Marketing Research, 13 (May). 168-172. 
Bernard, P., Gervais, S., Allen, J., Campomizzi, S. and Klein, O. (2012). Integrating sexual objectification with object versus person recognition: The sexualized-body-inversion hypothesis, Psychological Science, 23. 469-471.

Biasia, F. Lurzer's intertnational archive advertising worldwide,

https://www.luerzersarchive.com/en/magazine/print-detail/francesco-biasia-21282.html, date of access, September 13, 2019.

Boddewyn, J. J. (2013.) Controlling sex and decency in advertising around the world, Journal of Advertising, 20(4). 25-35.

Booth, Paul (2010). Digital Fandom New Media Studies, New York, Peter Lang Pub.

Bordo, Susan (1989). The body and the reproduction of femininity: A feminist approppriation of Foucault, Jaggar, A. and Bordo, S. (Ed), Gender/Body/Knowledge: Feminist Reconstruction of Being and Knowing, London, Rutgers University Press, 13-33.

Botterill, J., Macrury, I. and Richards, B. (2013). The Dynamics of Advertising, London, Kindle Edition Routledge.

Cammaerts, Bart (2011). Disruptive sharing in a digital age: Rejecting neoliberalism?, Continuum: Journal of Media and Cultural Studies, 25(1), 47-62.

Courtney, A. F. and Lockeretz, S. W. (1971). A Woman's Place: Analysis of the Roles Portrayed by Women in Magazine Advertisements, Journal of Marketing Research, 8 (1), 92-95.

Cutler, B. D. \& Javalgi, R. G. (1993). Analysis of Print Ad Features: Services Versus Products, Journal of Advertising Research, 33 (March/April), 62-69.

Davies, E. (2012). Successful Marketing in a Week: Teach Yourself, London, Hodder Education.

Dines, G., Jensen, R. \& Gusso, A. (1998). Pornography: The Production and Consumption of Inequality, USA, Routledge.

Ducoffe, H. R. (1995). How Consumers Assess the Value of Advertising, Journal of Current Issues and Research in Advertising, 17 (Spring), 1-18. 21-35.

Duncan, T. and Moriarty, S. E. (1998). A Communication-Based Marketing Model for Managing Relationships, Journal of Marketing 62(2) (April), 1-13.

Fashion Channel, (2014). Cara Delevinge for Pepe Jeans London Behind the scene Fall Winter 2014, https://www.youtube.com/watch?v=aRZzBW-9MyM , date of access, September 13, 2019.

Feng, Y., Chen, H. and He, L. (2019). Consumer responses to Femvertising: A Data-Mining Case of Dove's campaign for real beauty on YouTube, Journal of Advertising, 48, 292-301.

Ferguson, J. H., Kreshel, P. J. and Tinkham, S. E. (1990). In the Pages of Ms.: Sex role portrayals of Women in advertising, Journal of Advertising, 19(1), 40-51.

Fredrickson, B. L. and Roberts, T-A. (1997). Objectification Theory Toward Understanding Women's Lived Experiences and Mental Health Risks, Psychology of Women Quarterly, 21, 173-206.

Fritz, N. K. (1979). Claim recall and irritation in television commercial: An advertising effectiveness study, Journal of Academy of Marketing Science, 7(1-2), 1-13.

Graber, D. A. (2010). Mass Media and American Politics, 8th ed. Washington, DC, CQ Press.

Grau, S. L. and Zotos, Y. C. (2016). Gender stereotypes in advertising: a review of current research, International Journal of Advertising, 35(5), 761-770. 
D. Z. Bayazit 12/1 (2020) 429-439

Green, D. (2013). The 10 Sleaziest Car ads of the Century" Business Insider, (30 March), https://www.businessinsider.com/sleaziest-car-ads-of-the-21st-century-2013-3 , date of access, September 13, 2019.

Gudekli, I. A. and Celik, I. (2014). Using woman in advertisement as a symbol of sex: cosmopolitan magazine example, Journal of Yasar University, 9(35), 6099-6260.

Hackley, C. (2005). Advertising and Promotion-Communicating Brands, London, Sage pub.

Hall, S. (1997). Representations: Cultural Representations and Signifying Practices, $1^{\text {st }}$ Ed., London, Sage Pub.

Heflick, N. A. and Goldenberg, J. L. (2014). Seeing Eye to Body: The literal Objectification of Women, Current Directions in Psychological Science, 23(3), 225-229.

Kates, S. M. and Shaw-Garlock, G. (1999). The Ever Entangling Web: A Study of Ideologies and Discourses in Advertising to Women, Journal of Advertising, 28(2), 33-49.

Kilbourne, J. (2012). Advertising and Disconnection, Reicher, T. and Lambiase, J. (Ed.), Sex in Advertising Perspectives on the Erotic Appeal, NY, Routledge, 173-180.

Kim, N. Y. (2018). The Effect of Advertising Content Control on Advertising Effectiveness in The Different Forced Exposure Circumstance, Journal of Promotion Management, 24(6), 845-862.

Kose, H. (2011). Tüketim Toplumunda Bir 'Sosyal Beden' Kurgusu Olarak Kadın, Journal of Selcuk Communication, 6 (4), 76-89.

Kyrousi, A.G., Panigyrakis, G. G. and Panopoulos, A. P. (2016). Attitudes toward ads portraying women in decorative roles and female competition: an evolutionary psychology perspective, International Journal of Advertising, 35 (5), 771- 798.

Leigh, T. W., Rethans, A. J. and Whitney, T. R. (1987). Role portrayals of women in advertising: Cognitive responses and advertising effectiveness, Journal of Advertising Research, (October/November), 54-63.

Lundstrom, W. J., White, D. S. and Chopoorian, J. A. (1999). Attitudes of Contemporary European Women Toward Sex Role Portrayal, Company Image and Purchase Intention: The French versus U.S. Experience, Journal of Marketing Management, 15, 485-493.

Malthouse, E. C. and Li, H. (2017). Opportunities for and Pitfalls of Using Big Data in Advertising Research, Journal of Advertising, 46 (2), 227-235.

Mcguire, W. J. (1985). Attitudes and Attitude Change, Lindzey, G. and Aronson, E. (Ed.), Handbook of Social Psychology Vol. 2. Special Fields and Applications, 3rd, New York: Random House, 233-346.

Mick, D. G. and Politi, L. G. (1989).Consumers' Interpretations of Advertising Imagery: A Visit to the Hell of Connotation, Interpretive Consumer Research, 85-96.

Moore, D. J., Harris, W. D. and Chen, H. C. (1995). Affect intensity: An individual difference response to advertising appeals, Journal of Consumer Research, 22(2), 154-164.

Moriarty, S., Wells, W. and Burnett, J. (2006). Advertising Principles and Practices, $7^{\text {th }}$ Ed., USA, Pearson.

Nan, X. and Faber R. J. (2004). Advertising Theory: Reconceptualizing the building blocks, Marketing Theory, $4(1 / 2), 7-30$.

Neumann M. M. and Neumann, D. L. (2015). Touch Screen Tablets and Emergent Literacy, Journal of Early Childhood Literacy, 17(2), 203-220.

Onay, A. (2017). Men in Turkey and Their Changing Images in Magazine Advertisements, Istanbul University of Faculty of Communication Journal, 53, 165-188.

Paxson, P. (2018). Mass Communications and Media Studies: An Introduction, 2nd Ed., New York, Bloomsbury Academic.

Pedersen, P. M. (2002). Examining equity in newspaper photographs, International Review for the Sociology of Sport, 37(3), 303-318. 


\section{Z. Bayazit 12/1 (2020) 429-439}

Reichert, T. (2002). Sex in advertising research: A review of content, effects, and functions of sexual information in consumer advertising, Annual Review of Sex Research, 13(1), 241-273.

Richmond, D. and Hartman, T. (1982). Sex appeal in advertising, Journal of Advertising Research, 22, 53-61.

Rossiter, J. R. and Percy, L. (1985). Advertising Communication Models, Advances in Consumer Research, 12(1), 510-524.

Samsung (2010). True beauty is curved Campaign, https://www.adsoftheworld.com/media/print/samsung true beauty is curved, date of access, September 10, 2019.

Sharp,G. (2009). Redtape Shoes ‘Live Your Fantasy' Campaing, https://thesocietypages.org/socimages/2009/12/26/redtape-shoes-live-your-fantasy-campaign/ date of access, September 12, 2019.

Soley, L. and Reid, L. N. (1988). Taking it off: Are models in magazine ads wearing less?, Journalism and Mass Communication Quarterly, 65 (Winter), 960-966.

Sparks, J. V. and Lang, A. (2015). Mechanisms underlying the effects of sexy and humorous content in advertisements, Communication Monographs, 82(1), 134-162.

Stern, Barbara B. (1988). How Does an Ad Mean? Language in Services Advertising, Journal of Advertising, 17 (2), 3-14.

(1989). Literary Criticism and Consumer Research: Overview and Illustrative Analysis, Journal of Consumer Research, 16 (Dec), 322-334.

----- (1994). A Revised Communication Model for Advertising: Multiple Dimensions of the Source, the Message, and the Recipient, Journal of Advertising, 23(2), 5-15.

Stern, B. L., Krugman, D. M. and Resnik, A. (1981). Magazine Advertising: An Analysis of Its Information Content, Journal of Advertising Research, 21 (April), 39-44.

Solomon, B. (1992). The 90's woman makes strides down Madison Avenue, Management Review, 81(3), 11-16.

Sutcliffe, A. (2008). Multimedia and Virtual Reality Designing Multisensory User Interfaces, London: Taylor \& Francis e-Library.

Taylor, Charles R. (2009). Editorial: The six principles of digital advertising, International Journal of Advertising, 28 (3), 411-418.

Turley, L.W. and Kelley, S. W. (1997). A Comparison of Advertising Content: Business to Business versus Consumer Services, Journal of Advertising, 26 (4), 39-48.

Ulusoy, B. S. (2007). Kadınlara Yönelik Reklamlarda Etik Sorunlar ve Yeni Paradigmalar, Halkla Iliş,kiler ve Reklam Użerine Etik Degěrlendirmeler, ed. I. Sayımer and P. E. Yayınoglu, pp. 307-351, Istanbul, Beta.

Warne, C. E. (1962). Advertising-A Critic's View, Journal of Marketing, 26 (1), 10-14.

Whipple, T. W. and Courtney, A. E. (1985). Female role Portrayals in advertising and communication effectiveness: a review, Journal of Advertising, 14(3), 4-17.

Zimmerman, A. and Dahlberg, J. (2008). The sexual objectification of women in advertising: A contemporary cultural perspective, Journal of Advertising Research, 48(1): 71-79. 